\begin{tabular}{|l|l|l|}
\hline \multicolumn{2}{|c|}{ PublisherInfo } \\
\hline \hline PublisherName & $:$ & BioMed Central \\
\hline \hline PublisherLocation & $:$ & London \\
\hline \hline PublisherImprintName & $:$ & BioMed Central \\
\hline \hline
\end{tabular}

\title{
Chromosome conformation
}

\begin{tabular}{|l|l|l||}
\hline \multicolumn{2}{|c||}{ ArticleInfo } \\
\hline \hline ArticleID & $:$ & 4404 \\
\hline \hline ArticleDOI & $:$ & 10.1186 /gb-spotlight-20020218-02 \\
\hline \hline ArticleCitationID & $:$ & spotlight-20020218-02 \\
\hline \hline ArticleSequenceNumber & $:$ & 70 \\
\hline \hline ArticleCategory & $:$ & Research news \\
\hline ArticleFirstPage & $:$ & 1 \\
\hline \hline ArticleLastPage & $:$ & 2 \\
\hline \hline & & RegistrationDate : 2002-2-18 \\
\hline ArticleHistory & $:$ & OnlineDate \\
\hline \hline ArticleCopyright & $:$ & BioMed Central Ltd2002-18 \\
\hline \hline ArticleGrants & $:$ & \\
\hline \hline ArticleContext & $:$ & 130593311 \\
\hline \hline
\end{tabular}




\section{Jonathan B Weitzman}

Email: jonathanweitzman@hotmail.com

In the February 15 Science, Dekker et al. describe an ingenious high-throughput method to analyse the spatial organization and physical properties of whole chromosomes (Science 2002, 295:1306-1311). They call their technique 'chromosome conformation capture' (3C); it involves the isolation of intact nuclei, followed by formaldehyde fixation which causes cross-linking of genomic segments that are in contact via their DNA-bound proteins. The cross-linking frequencies can then be measured by restriction enzyme digestion, ligation of intramolecular fragments and detection by PCR amplification. Dekker et al. applied the technique to analysis of chromosome III of Saccharomyces cerevisiae, and could show that the telomeres are in close spatial proximity and that there are dynamic changes in centromere interactions during meiosis. AT- and GC-rich domains exhibited different curved conformations and constraints. Dekker et al. also demonstrate that the $3 \mathrm{C}$ technique can be used to analyse chromatin flexibility and the importance of looping and long-range interactions along the chromatin fibre.

\section{References}

1. Science, [http://www.sciencemag.org] 